\title{
Growth and yield of non-grafted and grafted tomato (Solanum lycopersicum L.) cultivars grown in two cultivation systems
}

\author{
Zenaida C. Gonzaga ${ }^{1 *}$, Lester F. Legaspi', Lucia M. Borines' ${ }^{1}$ Othello B. Capuno', \\ Jessie C. Rom', Ana Linda G. Gorme', Sandra McDougall', Adam D. Goldwater ${ }^{3}$ \\ and Gordon S. Rogers ${ }^{3}$
}

\begin{abstract}
Tomato is a high-value vegetable crop because of its broad culinary uses and nutritional values. Its production however is inhibited in some areas with soil-borne disease problems, particularly bacterial wilt. This study was conducted to evaluate the yield, bacterial wilt infection, and profitability of non-grafted and grafted tomato cultivars planted in open field and protected cultivation. Protected cropping of tomato increased number of marketable fruits and total yield by approximately 2 times fold than those grown in open field. Grafting of the cultivars to eggplant significantly reduced bacterial wilt infection such that increased survival among plants resulted to higher yield than non-grafted. The cultivar with biggest fruits was from 'Kingkong' while season red had the smallest and other cultivars were in average size of the two. Grafted 'Diamante max' cultivar yielded the highest followed by 'Season red'. Net return of protected cropping tomato was higher than in open field. Non-grafted tomato grown in bacterial wilt infected area was unprofitable. On the other hand, grafting and protected resulted in better yield, gross income and a positive net return. Season red produced the highest income in the open field while Diamante max for protected cultivation. The use of grafted tomato and protective structure are strongly recommended for planting in areas known to have high bacterial wilt.
\end{abstract}

Keywords: Ralstonia solanacearum, nightshade family, rain shelter, tolerance, semi-determinate, cleft grafting

\footnotetext{
'Visayas State University, Leyte, Philippines

${ }^{2}$ Department of Primary Industries (DPI), Australia

${ }^{3}$ Applied Horticultural Research, Sydney, Australia
}

\footnotetext{
* Corresponding Author. Address: Department of Horticulture, Visayas State University, Visca, Baybay City, Leyte, 6521-A Philippines; Email:zcgonzaga@yahoo.com DOI: 10.32945/atr39sb12.2017
} 
Growth and yield of non-grafted and grafted tomato

\section{INTRODUCTION}

Tomato (Solanum lycopericum L.) is one of the most widely grown vegetables in the world because it can be eaten fresh or in processed forms. It is grown in approximately 3.58 million hectares and has a total world production of $90,895,577$ tons (FAOSTAT 2000). In recent decades, the consumption of tomatoes has been associated with prevention of several diseases (Willcox et al 2003, Sharoni \& Levi 2006), because it contains antioxidants including carotenes (Lycopene as well as $\beta$ carotene), ascorbic acid, and phenolic compounds (Periago et al 2009). Tomato is a good source of vitamins, minerals, calcium and niacin which protect the body against diseases (Taylor 1987).

Despite its nutritional and economic value, tomato production has encountered several production challenges, including. Bacterial wilt, caused by Ralstonia solanacearum, can be a significant problem for tomato growers because of the complex biology of the pathogen, potential severity of the disease, and lack of effective management strategies (Buddenhagen et al 1964, Hayward 1991). Bacterial wilt is a serious disease in ACIAR-ICM (Australian Centre for International Agricultural Research-Integrated Crop Management) field which infects solanaceous and cucurbit crops (Borines et al 2016, Dimabuyu et al 2016, Gorme 2016, Lacostales 2015, Sumalinog 2015, Tuyan 2015, Gonzaga et al 2013, Abrantes 2013).

One of the major goals of vegetable industry is year-round and increased production. One way to accomplish these are through protected cropping where climatic variables such as rainfall, air and soil temperatures, and also $\mathrm{CO} 2$ air concentration are regulated/controlled (Sandri et al 2003). Protective structures increase crop yield and quality by altering environmental factors, such as light, temperature, air humidity, wind, and/or pest pressure (Santos et al 2013). Gonzaga et al (2013) reported that this technology was able to reduce incidence of diseases, particularly bacterial wilt since the amount of water the plant receives under the structure can be regulated.

Other management practices that improve crop productivity and lessen the outbreak of bacterial wilt and other soil-borne diseases is through grafting. Khah et al (2006) showed that tomato grafting on suitable rootstocks has positive effects on cultivation performance, especially in greenhouse conditions. It was found that grafted tomato on eggplant rootstock showed promising results for control of multiple pathogens (loannou 2001). R. solanacearum infects tomato roots through wounds or natural openings, colonizes the xylem, and produces extracellular polysaccharides that clog the vascular tissue (Kelman 1993). Hence, grafting between tomato and eggplant which is called "kamlong" has been reported to solve the bacterial wilt problem (Aganon et al 2004).

A previous study under the Australian Centre for International Agricultural Research-Integrated Crop Management project at Visayas State University (VSU) successfully grafted the 'Diamante max' tomato as to eggplant rootstock, however comparison with other cultivars was not done. Likewise, comparison of performance of cultivars in the open field and protected cultivation system was limited. Considering the above premise, the performance of different tomato cultivars grafted to eggplant, and comparison with non-grafted plants, was evaluated in the open field and protected cultivation. 
Gonzaga et al

\section{MATERIALS AND METHODS}

\section{Site Description}

This study was conducted in the Australian Centre for International Agricultural Research-Integrated Crop Management (ACIAR-ICM) project site of the Department of Horticulture, Visayas State University. The area was known to have bacterial wilt contamination as determined by Philippine Diagnostic Disease Laboratory (PDDL) of the University as determined by Ooze test of previously planted tomatoes and Immunostrip diagnostic kit.

\section{Protective Structure}

A house-type protective structure with curved bamboo roofing was used in this study. The structure had open sides for good ventilation, and an inner area of $200 \mathrm{~m}^{2}$ ie, $5 \mathrm{mx} 40 \mathrm{~m}$. The roof was covered with $0.002 \mathrm{~mm}$ UV-treated plastic, standing $4 \mathrm{~m}$ high.

\section{Experimental Design and Treatments}

Both study of non-grafted and grafted tomatoes were arranged in randomized complete block design with three replications. Each study had two factors with type of cultivation as the main plot and different cultivars as the sub-plot. The type of cultivation used were conventional ie, open field and protected cultivation using house-type structure. Cultivars as sub-plot were 'Agatona', 'Discovery', 'Atlas', 'Diamante max', 'Kingkong', and 'Season red'.

\section{Grafting Procedure}

Seedlings were grafted after 2 to 3 true leaves had developed in both tomato and eggplant seedlings. Their stems were approximately $1.6-1.8 \mathrm{~mm}$ at the point of excision. This stage of development typically required 14 to 16 days after germination of tomato seedlings.

The eggplant was cut at a $30^{\circ}$ angle, slightly above the cotyledons. A place on the tomato stem was selected for cutting to ensure that the tomato scion diameter matched the eggplant stem diameter. The cut portion of the scion and stock was joined, and both ends inserted into a latex tube. The tube held the graft union and prevented desiccation. The latex tube split open as the point of union healed and the stem enlarged.

Right after grafting, the seedlings were transferred to a shaded chamber with temperatures ranging from $25-32^{\circ} \mathrm{C}$. A shallow layer of water was kept on the floor and the doors were closed to maintain high humidity $(>85 \% \mathrm{RH})$ to facilitate healing of the graft. The grafted tomatoes were placed in elevated wood blocks with firm plastic screens to support the plants above the water. Four to five days after grafting, the hardening process was done by opening the chamber's plastic-covered door, but keeping the screen door closed to prevent insect infestation. The chamber was opened for 3-5min to flush carbon dioxide and air pollutants and this was done 2-3 times on the same day. The conditions were maintained for two to three days prior to moving the grafted plants out of the chamber and into the nursery. Nine days 
Growth and yield of non-grafted and grafted tomato

after grafting, starter solution was applied ( $10 \mathrm{~g}$ Calcium nitrate). The plants were held in the nursery for seven to eight days for further development and hardening. The entire process took 30 to 33 days from sowing.

\section{Fertilization and Irrigation}

Fertilizer application of $90-60-60 \mathrm{~kg} \mathrm{~N}, \mathrm{P}_{2} \mathrm{O}_{5}, \mathrm{~K}_{2} \mathrm{O}$ per hectare using complete (16$16-16 \mathrm{NPK})$ and calcium nitrate $\left(19 \% \mathrm{Ca} \& 15.5 \% \mathrm{NO}_{3}\right)$ were applied at planting basally. The newly planted seedlings were watered immediately to hasten recovery from transplanting stress. Drip irrigation was used to water plants depending on the moisture condition of the soil. One week after transplanting, plants were drenched with calcium nitrate at a concentration of $250 \mathrm{~g}$ per $50 \mathrm{~L}$ of water, with $150 \mathrm{~mL}$ applied perplant.

\section{Data Analysis}

The data gathered on non-grafted tomatoes was not statistically analyzed, as it was unsuitable for any statistical procedure due to high mortality. Non-grafted and grafted data comparison were not also statistically run due to similar reason. On the other hand, the grafted tomatoes were analyzed using ANOVA by Statistical Tool for Agricultural Research (STAR) version 2.0.1 and means were compared using Tukey's honest significant difference at $5 \%$ level of significance. The statistical analysis was supervised by the department of statistics of the Visayas State University.

\section{RESULTS AND DISCUSSION}

\section{Flowering, Fruiting and Harvesting Characteristics}

The non-grafted 'Diamante max' took the shortest time to flower from transplanting in the open field, and season red in protected cropping (Table 1). The protection provided by the structure resulted in flowering two days earlier than in the open field. Non-grafted Discovery, Season red and Kingkong were not able to bear flowers and fruits because of low survival (Table 3 ) as a result from highly susceptible to bacterial wilt, with infection starting at an early stage of growth (Table 4).

On the other hand, grafted tomato cultivars showed significant differences in the number of days to first flowering and fruiting, however the type of cultivation did not influence these characteristics (Table 5). This implies that grafted tomato will flower in 32 to 33 days and bear fruits 40-41 days from transplanting with respect to condition of experimental site.

There was interaction effect of type of cultivation and cultivars on days to first harvest where 'Diamante max' was harvested earlier when grown under protective structure ie, 60 days and 67 days in open field but 'Agatona' resulted in reverse ie, 60 and 57 days, protected and open field, respectively. The other cultivars were almost similar in days to first harvest between the two cultivation systems. This difference in response could mainly be attributed by genetic variability among cultivars where fruits of 'Agatona' mature early in open field due to maybe of direct sunlight. 
'Diamante max' may have favoured early development of fruits under structure as minimal stress experienced unlike in open field where frequent wetting from rain occurred.

Table 1. Means number of days to flowering, fruiting and harvesting of non-grafted tomato (Solanum lycopersicum L.) as influenced by type of cultivation and cultivars planted in ACIAR-ICM site, Department of horticulture, Visayas State University, Visca, Baybay City, Leyte

\begin{tabular}{|c|c|c|c|c|c|c|}
\hline \multirow{3}{*}{ Cultivar } & \multicolumn{6}{|c|}{ Days to } \\
\hline & \multicolumn{2}{|c|}{ Flowering } & \multicolumn{2}{|c|}{ Fruiting } & \multicolumn{2}{|c|}{ Harvesting } \\
\hline & $\begin{array}{l}\text { Open } \\
\text { field }\end{array}$ & $\begin{array}{c}\text { Pro- } \\
\text { tected }\end{array}$ & $\begin{array}{l}\text { Open } \\
\text { field }\end{array}$ & $\begin{array}{c}\text { Pro- } \\
\text { tected }\end{array}$ & $\begin{array}{l}\text { Open } \\
\text { field }\end{array}$ & Pro- tected \\
\hline Agatona & 31.83 & 27.01 & 37.23 & 33.13 & 57.00 & 53.00 \\
\hline Discovery & - & 28.17 & - & - & - & - \\
\hline Atlas & 30.88 & 27.63 & 38.17 & 34.00 & 57.00 & 52.00 \\
\hline Diamante max & 27.07 & 28.06 & 34.67 & 34.33 & 63.67 & 52.33 \\
\hline Kingkong & - & 28.10 & - & - & - & - \\
\hline Season red & - & 24.89 & - & - & - & - \\
\hline Mean & 29.93 & 27.79 & 36.69 & 33.82 & 59.22 & 52.44 \\
\hline
\end{tabular}

Means are not statistically analysed due to inapplicability of data.

Table 2. Mean marketable, non-marketable and total yield of non-grafted tomato (Solanum lycopersicum L.) as influenced by type of cultivation and cultivars planted in ACIAR-ICM site, Department of horticulture, Visayas State University, Visca, Baybay City, Leyte

\begin{tabular}{|c|c|c|c|c|c|c|}
\hline \multirow{3}{*}{ Cultivar } & \multicolumn{6}{|c|}{ Fruit weight } \\
\hline & \multicolumn{2}{|c|}{$\begin{array}{c}\text { Marketable } \\
\left(\mathrm{kg} \text { per } 2.5 \mathrm{~m}^{2}\right)\end{array}$} & \multicolumn{2}{|c|}{$\begin{array}{c}\text { Non-marketable } \\
\left(\mathrm{kg} \text { per } 2.5 \mathrm{~m}^{2}\right)\end{array}$} & \multicolumn{2}{|c|}{$\begin{array}{c}\text { Total yield } \\
\left(\mathrm{t} \mathrm{ha}^{-1}\right)\end{array}$} \\
\hline & $\begin{array}{l}\text { Open } \\
\text { field }\end{array}$ & Protected & $\begin{array}{l}\text { Open } \\
\text { field }\end{array}$ & Protected & $\begin{array}{l}\text { Open } \\
\text { field }\end{array}$ & Protected \\
\hline Agatona & 0.37 & 0.35 & 0.10 & 0.31 & 1.86 & 2.68 \\
\hline Discovery & - & - & - & - & - & \\
\hline Atlas & 0.38 & 0.77 & 0.10 & 0.41 & 1.94 & 4.70 \\
\hline Diamante max & 0.07 & 0.25 & 0.04 & 0.18 & 0.45 & 1.72 \\
\hline Kingkong & - & - & - & - & - & - \\
\hline Season red & - & - & - & - & - & - \\
\hline Mean & 0.27 & 0.46 & 0.08 & 0.30 & 1.42 & 3.03 \\
\hline
\end{tabular}

Table 3. Mean percentage survival of non-grafted tomato (Solanum lycopersicum L.) planted at ACIAR-ICM site, Department of horticulture, Visayas State University, Visca, Baybay City, Leyte

\begin{tabular}{lcccccc}
\hline \multirow{3}{*}{ Cultivar } & \multicolumn{7}{c}{ Survival (\%) } \\
\cline { 2 - 7 } & \multicolumn{2}{c}{$1^{\text {st }}$ month } & \multicolumn{2}{c}{$2^{\text {nd }}$ month } & \multicolumn{2}{c}{$3^{\text {rd }}$ month } \\
\cline { 2 - 7 } & $\begin{array}{c}\text { Open } \\
\text { field }\end{array}$ & $\begin{array}{c}\text { Protect } \\
\text { ed }\end{array}$ & $\begin{array}{c}\text { Open } \\
\text { field }\end{array}$ & Protected & Open field & Protected \\
\hline Agatona & 93.33 & 83.33 & 90.00 & 83.33 & 80.00 & 73.33 \\
Discovery & 20.00 & 40.00 & - & 33.33 & - & - \\
Atlas & 93.33 & 60.00 & 80.00 & 53.33 & 70.00 & 46.67 \\
Diamante max & 30.00 & 20.00 & 26.67 & 6.67 & 20.00 & 20.00 \\
Kingkong & 16.67 & 16.67 & - & 13.33 & - & - \\
Season red & 16.67 & 13.33 & - & 6.67 & - & - \\
\hline \multicolumn{1}{c}{$\quad$ Mean } & 50.67 & 38.89 & 65.56 & 32.78 & 56.67 & 46.67 \\
\hline
\end{tabular}

Means are not statistically analysed due to inapplicability of data. 
Growth and yield of non-grafted and grafted tomato

Table 4. Means BWI of non-grafted tomato (Solanum lycopersicum L.) planted in ACIAR-ICM site, Department of horticulture, Visayas State University, Visca, Baybay City, Leyte

\begin{tabular}{lcccccc}
\hline \multirow{2}{*}{ Cultivar } & \multicolumn{7}{c}{ Bacterial wilt Infection (\%) } \\
\cline { 2 - 7 } & \multicolumn{2}{c}{$1^{\text {st }}$ month } & \multicolumn{2}{c}{$2^{\text {nd }}$ month } & \multicolumn{2}{c}{$3^{\text {rd }}$ month } \\
\cline { 2 - 7 } & $\begin{array}{c}\text { Open } \\
\text { field }\end{array}$ & Protected & Open field & Protected & Open field & Protected \\
\hline Agatona & 6.67 & 16.67 & 10.00 & 16.67 & 20.00 & 26.67 \\
Discovery & 80.00 & 60.00 & 100.00 & 66.67 & 100.00 & 100.00 \\
Atlas & 6.67 & 40.00 & 20.00 & 46.67 & 30.00 & 53.33 \\
Diamante max & 70.00 & 80.00 & 73.33 & 80.00 & 80.00 & 80.00 \\
Kingkong & 86.67 & 83.33 & 100.00 & 86.67 & 100.00 & 100.00 \\
Season red & 83.33 & 86.67 & 100.00 & 93.33 & 100.00 & 100.00 \\
\hline \multicolumn{1}{c}{$\quad$ Mean } & 50.00 & 61.11 & 60.67 & 67.22 & 66.00 & 76.67 \\
\hline
\end{tabular}

Means are not statistically analysed due to inapplicability of data.

Table 5. Mean number of days from transplanting to first flowering and fruiting of grafted tomato (Solanum lycopersicum L.) as influenced by type of cultivation and cultivars planted in ACIAR-ICM site, Department of horticulture, Visayas State University, Visca, Baybay City, Leyte

\begin{tabular}{lll}
\hline \multirow{2}{*}{ Treatments } & \multicolumn{2}{c}{ Number of days to first } \\
\cline { 2 - 3 } & Flowering & Fruiting \\
\hline Types of Cultivation & 32.56 & 40.43 \\
Open Field & 33.78 & 41.18 \\
Protected & & \\
Cultivars & $31.95 \mathrm{bc}$ & $38.13 \mathrm{~b}$ \\
Agatona & $33.19 \mathrm{abc}$ & $42.99 \mathrm{a}$ \\
Discovery & $33.20 \mathrm{abc}$ & $40.24 \mathrm{ab}$ \\
Atlas & $35.88 \mathrm{a}$ & $43.31 \mathrm{a}$ \\
Diamante max & $34.03 \mathrm{ab}$ & $42.78 \mathrm{a}$ \\
Kingkong & $30.77 \mathrm{c}$ & $37.37 \mathrm{~b}$ \\
Season red & &
\end{tabular}

from each other using Tukey's hsd at $5 \%$ level.

\section{Yield and Yield Components}

Non-grafted Agatona, Atlas, and Diamante max were able to produce fruit (Table 2), but Discovery, Season red and Kingkong had zero yield due to BWI (Table 4). This proved the claim from the seed company of 'Agatona, 'Atlas' and 'Diamante max' that possess medium resistance to bacterial wilt. The highest yielder in this condition was 'Atlas' which obtained $4.7 \mathrm{t} \mathrm{ha}^{-1}$.

On the grafted tomatoes, the number and weight of marketable fruits under the protective structure was significantly higher, than in the open field (Table 6). Likewise, total yield of protected tomato plants was twice that of the open field. This could be due to frequent wetting and waterlogging experienced by plants in the open field which resulted in lower survival rate than plants under the structure (Table 8). This result is in consonance with the reports of Gorme (2016), Lusanta (2016) and Sumalinog (2015), that higher yields were noted under protective structures than that in the open field. Protected cropping technology, as reported can reduce the incidence of diseases since the amount of water the plant receives under structure can be regulated (Gonzaga et al 2013). 
The 'Season red' cultivar obtained the highest number and heaviest weight of marketable fruits, and consequently the highest total yield regardless of cultivation system used. There was more than doubled the number of fruits from 'Season red' (474) than the second highest (Diamante max) with 209 only. The cultivars with least number of fruits were 'Discovery' and 'Kingkong'.

On fruit size, 'Season red' was the shortest in polar and equatorial diameters compared with other cultivars (Table 6). The small in size of fruit from this cultivar was attributed by genetic difference as this cultivar belong to cherry type tomato and was designed by tiny fruits. 'Kingkong' had the longest equatorial diameter as this categorized under salad type hybridized for big fruits. The other cultivars were almost similar in size which was the usual for local market preference in the area.

Table 6. Yield and yield components of grafted tomato (Solanum lycopersicum L.) as influenced by type of cultivation and cultivars planted in ACIAR-ICM site, Department of horticulture, Visayas State University, Visca, Baybay City, Leyte

\begin{tabular}{|c|c|c|c|c|c|}
\hline \multirow{2}{*}{ Treatments } & \multicolumn{2}{|c|}{ Fruit size $(\mathrm{cm})$} & \multicolumn{2}{|c|}{ Marketable fruits $\left(2.5 \mathrm{~m}^{2}\right)$} & \multirow{2}{*}{$\begin{array}{c}\text { Total yield } \\
\left(\mathrm{t} \mathrm{ha}^{-1}\right)\end{array}$} \\
\hline & Polar & Equatorial & Number & Weight $(\mathrm{kg})$ & \\
\hline \multicolumn{6}{|c|}{ Types of Cultivation } \\
\hline Open Field & 4.18 & 3.66 & $125.94 b$ & $2.45 b$ & $11.06 \mathrm{~b}$ \\
\hline Protected & 4.51 & 3.93 & $230.89 a$ & $5.50 a$ & $23.53 a$ \\
\hline \multicolumn{6}{|l|}{ Cultivars } \\
\hline Agatona & $5.01 a$ & $3.89 \mathrm{~b}$ & $127.00 \mathrm{~b}$ & $4.33 a b$ & 18.47ab \\
\hline Discovery & $4.60 a$ & $3.86 \mathrm{~b}$ & $50.00 \mathrm{c}$ & $1.86 \mathrm{c}$ & $8.75 b$ \\
\hline Atlas & $4.01 b$ & $3.66 \mathrm{~b}$ & $167.50 \mathrm{~b}$ & $4.08 \mathrm{abc}$ & 17.24ab \\
\hline Diamante max & $4.59 a$ & $3.93 b$ & $208.67 b$ & $5.40 \mathrm{a}$ & $22.61 a$ \\
\hline Kingkong & $4.94 a$ & $4.88 \mathrm{a}$ & $43.33 c$ & $2.27 \mathrm{bc}$ & $12.19 \mathrm{~b}$ \\
\hline Season red & $2.81 \mathrm{C}$ & $2.59 c$ & $474.00 \mathrm{a}$ & $5.92 a$ & $24.50 \mathrm{a}$ \\
\hline
\end{tabular}

Means within the same column in a block followed by the same letter and/or no letter designation are not significantly different from each other using Tukey's hsd at $5 \%$ level.

Significant interaction effects were observed on cultivars and cultivation system used on the number and weight of non-marketable fruits (Table 7). Highest number of non-marketable fruits in open field was 'Season red' while 'Discovery' and 'Kingkong' in protected cropping. This suggest of variability of fruit fly infestation in the area as the main cause of non-marketability of tomato was due to fruit fly larva damage. On the other hand, weight of non-marketable fruits in open field was similar but under protected cropping 'Kingkong' fruit weight was increased which was the highest. The increase in weight on fruits of 'Kingkong' was contributed by its big size of fruits though it was also one of the highest number in protected cropping similar to 'Discovery'. 
Growth and yield of non-grafted and grafted tomato

Table 7. Effects of type of cultivation and cultivars of grafted tomato (Solanum lycopersicum L.) on number of days to first harvest, number and weight of non-marketable fruits planted in ACIAR-ICM site, Department of horticulture, Visayas State University, Visca, Baybay City, Leyte

\begin{tabular}{|c|c|c|c|c|c|c|}
\hline \multirow{3}{*}{ Cultivar } & \multirow{2}{*}{\multicolumn{2}{|c|}{$\begin{array}{c}\text { Number of days to first } \\
\text { harvest }\end{array}$}} & \multicolumn{4}{|c|}{ Non-marketable fruits per $2.5 \mathrm{~m}^{2}$} \\
\hline & & & \multicolumn{2}{|c|}{ Number } & \multicolumn{2}{|c|}{ Weight } \\
\hline & Open field & Protected & Open field & Protected & Open field & Protected \\
\hline Agatona & $57.00 \mathrm{~b}$ & $60.33 b$ & $12.33 b$ & $11.00 \mathrm{ab}$ & $0.29 a$ & $0.29 \mathrm{~b}$ \\
\hline Discovery & $66.00 \mathrm{a}$ & $67.00 \mathrm{a}$ & $7.67 \mathrm{~b}$ & $21.33 a$ & $0.11 \mathrm{a}$ & $0.49 \mathrm{ab}$ \\
\hline Atlas & $57.00 \mathrm{~b}$ & $57.00 \mathrm{c}$ & $16.33 b$ & $12.67 a b$ & $0.26 a$ & $0.20 \mathrm{~b}$ \\
\hline Diamante max & $67.00 \mathrm{a}$ & $60.33 b$ & $11.33 b$ & $7.33 b$ & $0.23 a$ & $0.18 \mathrm{~b}$ \\
\hline Kingkong & $64.00 \mathrm{a}$ & $67.00 \mathrm{a}$ & $12.00 \mathrm{~b}$ & $24.33 a$ & $0.58 \mathrm{a}$ & $0.98 \mathrm{a}$ \\
\hline Season red & $57.00 \mathrm{~b}$ & $57.00 \mathrm{c}$ & $33.67 a$ & 16.33ab & $0.36 a$ & $0.14 b$ \\
\hline
\end{tabular}

Means within the same column followed by the same letter designation are not significantly different from each other using Tukey's hsd at $5 \%$ level.

\section{Survival and Wilt Incidence}

The survival of plants and BWI were inversely correlated as infection on the plant was the main cause of mortality. Non-grafted 'Atlas' and 'Agatona' had consistently higher survival rates from the first to third month compared to other cultivars (Table 3). This suggests they have some tolerance to bacterial wilt caused by Ralstonia solanacearum. Likewise, these two cultivars had lower bacterial wilt infection. Nongrafted 'Kingkong', 'Discovery' and 'Season red' succumbed to $100 \%$ BWI in the 2nd and 3rd month in open field which were month earlier than protected cropping.

These results support the findings of Gonzaga et al (2013) that incidence of diseases, particularly, $R$. solanacearum was generally higher in the open field than under protective structures. This was because excessive moisture and slow evaporation due to lower temperature (Figure 2) in the open field. Heavy rains form surface water which is conducive to the motile bacterial wilt pathogen $R$. solanacearum. Surface water run-off in other areas of the field also favours the dissemination of the water borne inoculum to other planted areas. Inside protective structures, moisture extremes were regulated.

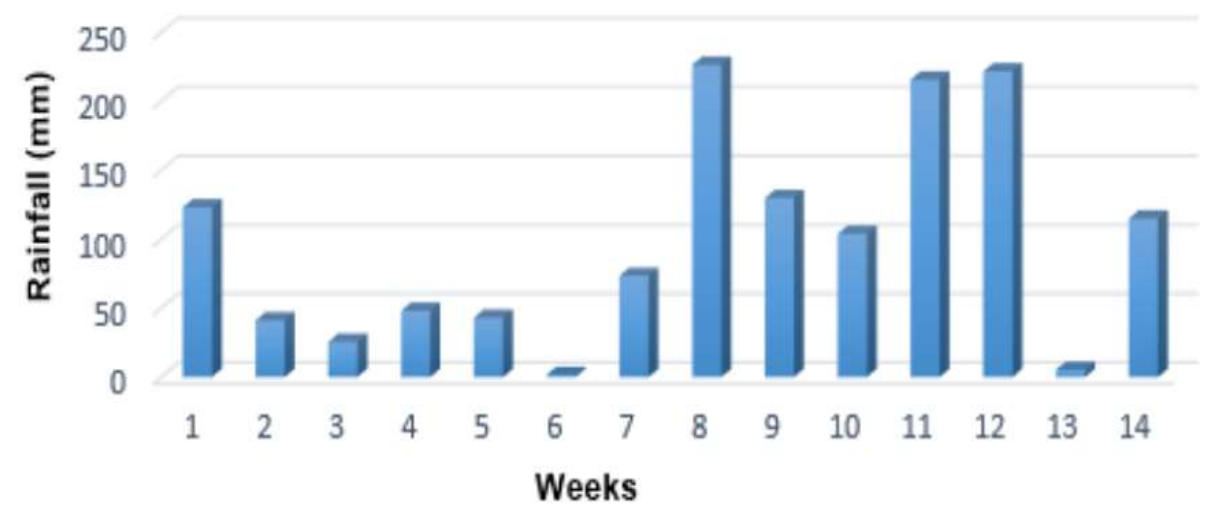

Figure 1. Total weekly rainfall $(\mathrm{mm})$ from July to October 2016 taken from PAG-ASA meteorological station, VSU, Visca, Baybay City, Leyte 
Gonzaga et al

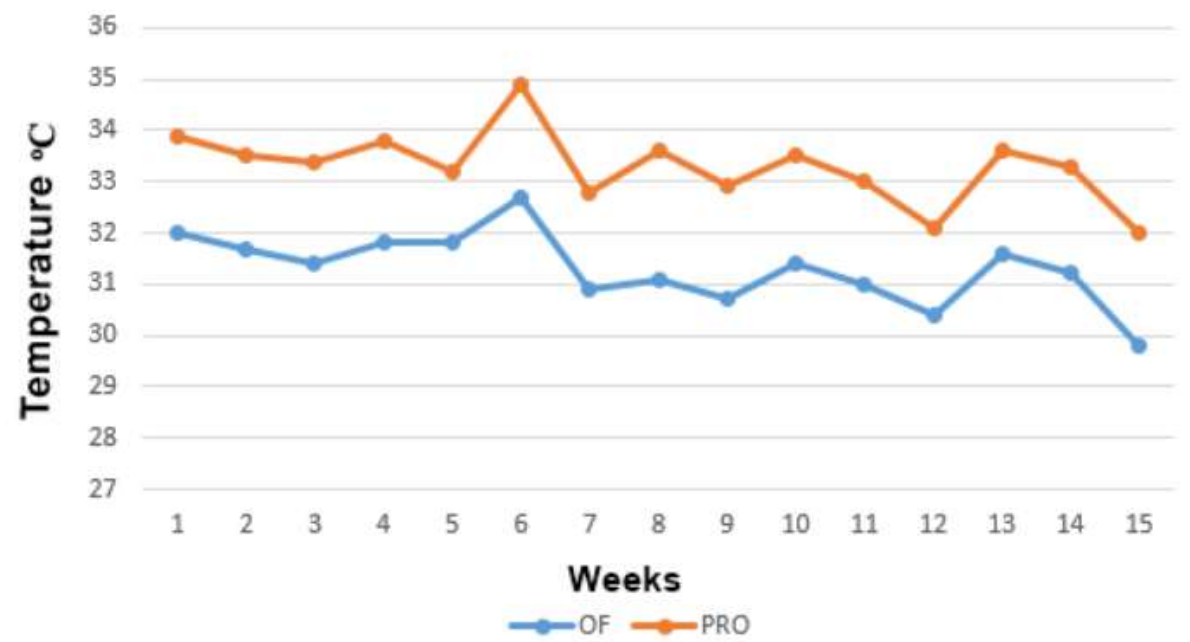

Figure 2. Average weekly temperature $\left({ }^{\circ} \mathrm{C}\right)$ from July to October 2016 taken from PAG-ASA meteorological station, VSU, Visca, Baybay City, Leyte

On the other hand, survival rate and BWI of grafted plants were statistically comparable in both types of cultivation and among different tomato cultivars from the first to third month of the experiment (Table 8). However, slightly difference of survival and BWI were numerically noted in cultivation system used on the third month where disadvantageous to open field. The open field plants although grafted were susceptible to infection by soil splash that occurred during heavy rain. This was believed that tiny adventitious roots in scion served as entry of pathogens.

Table 8. Percent survival and percent BWI of grafted tomato (Solanum lycopersicum $\mathrm{L}$ ) as influenced by type of cultivation and cultivars planted in ACIAR-ICM site, Department of horticulture, Visayas State University, Visca, Baybay City, Leyte

\begin{tabular}{lrrrrrr}
\hline \multirow{2}{*}{ Treatments } & \multicolumn{3}{c}{ Percent survival (\%) } & \multicolumn{3}{c}{ Bacterial wilt infection (\%) } \\
\cline { 2 - 5 } & $1^{\text {st }}$ Month & $2^{\text {nd }}$ Month & $3^{\text {rd }}$ Month & $1^{\text {st }}$ Month & $2^{\text {nd }}$ Month & $3^{\text {rd }}$ Month \\
\hline Types of & & & & & & \\
Cultivation & & & & & & \\
$\quad$ Open Field & 99.44 & 97.78 & 80.00 & 0.56 & 2.22 & 20.00 \\
$\quad \begin{array}{l}\text { Protected } \\
\text { Cultivars }\end{array}$ & 99.44 & 96.67 & 87.78 & 0.56 & 3.33 & 12.22 \\
$\quad$ & & & & & \\
Agatona & 100.00 & 98.33 & 88.33 & 0.00 & 1.67 & 11.67 \\
Discovery & 98.33 & 93.33 & 71.67 & 1.67 & 6.67 & 28.33 \\
Atlas & 100.00 & 100.00 & 88.33 & 0.00 & 0.00 & 11.67 \\
Diamante max & 100.00 & 100.00 & 95.00 & 0.00 & 0.00 & 5.00 \\
Kingkong & 100.00 & 95.00 & 75.00 & 0.00 & 5.00 & 25.00 \\
Season red & 98.33 & 96.67 & 85.00 & 1.67 & 3.33 & 15.00 \\
\hline Means within the same column in a block followed by the same and/or no letter designation are not significantly different \\
from each other using Tukey's hsd at 5\% level.
\end{tabular}


Growth and yield of non-grafted and grafted tomato

\section{Yield of Non-grafted and Grafted Tomato Cultivars}

The non-grafted plants resulted in zero yield using Discovery, Kingkong, and season red; and very low yield from remaining cultivars (Figure 3). Season red obtained the highest yield in open field using grafting technique and Diamante max in protected cropping. Open field cultivation had lower yields than protected cropping. Overall, grafted tomato production increased yield by more than $260 \%$ than non-grafted.

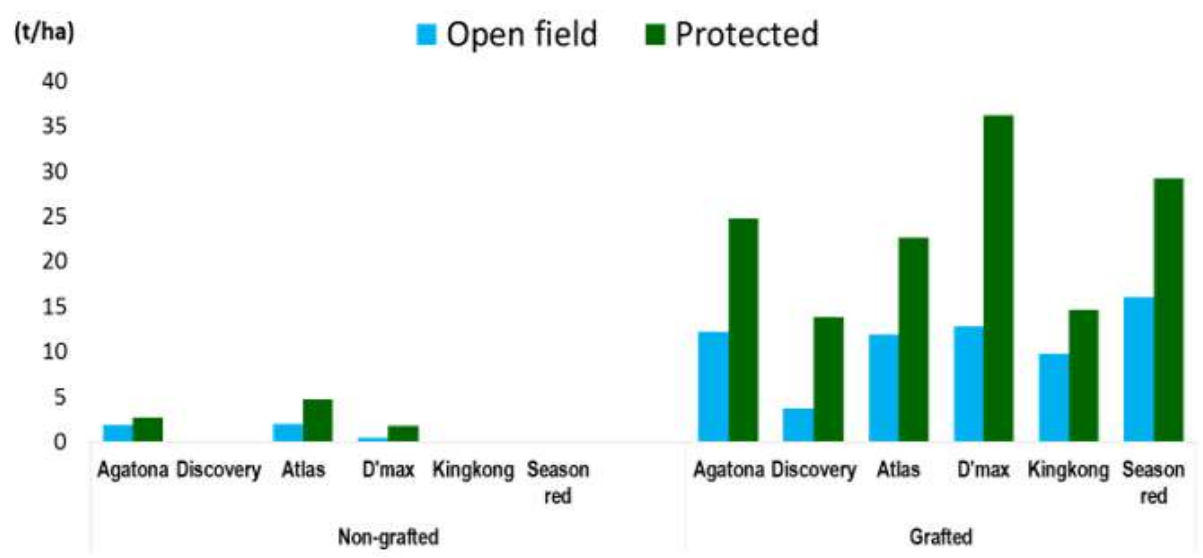

Figure 3. Comparison of yield between non-grafted and grafted tomato (Solanum lycopersicum L.) as influenced by type of cultivation and cultivars planted at ACIAR-ICM site, Department of horticulture, Visayas State University, Visca, Baybay City, Leyte on July to October 2016

\section{BWI of Non-grafted and Grafted Tomato Cultivars}

The higher bacterial wilt incidence caused by Ralstonia solanacearum in nongrafted tomatoes clearly manifested susceptibility of the different cultivars used except Agatona which has some tolerance to the disease (Figure 4). Most cultivars in the open field had higher bacterial wilt incidence than under protective structure. Grafted Diamante max under protective structure had the lowest wilt incidence compared to other cultivars and open field, respectively. 


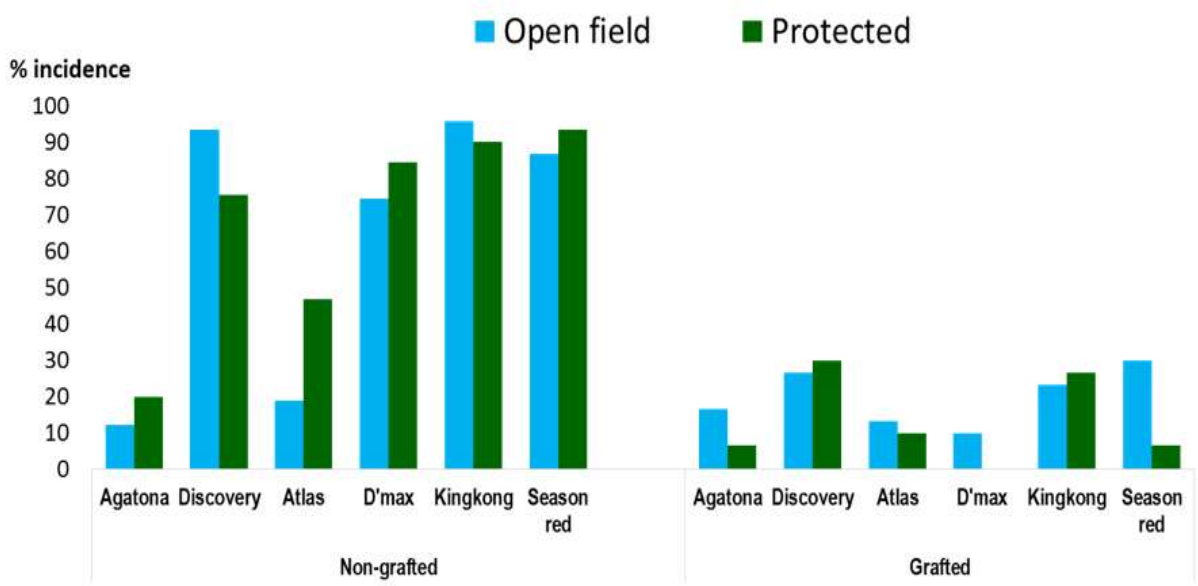

Figure 4. Comparison of bacterial wilt infention between non-grafted and grafted tomato (Solanum lycopersicum L.) as influenced by type of cultivation and cultivars planted at ACIAR-ICM site, Department of horticulture, Visayas State University, Visca, Baybay City, Leyte on July to October 2016

\section{Cost and Return Analysis}

Results of non-grafted tomato profitability were clearly evident to net loss due to very low/zero yield. On the other hand, grafted cultivars under the protected structure generated higher net income than in the open field (Table 9). Season red obtained the highest total yield, gross income and net return under open field. Under protected cropping, Diamante max had the highest yield, gross income and net return of PHP25,731.43 per $200 \mathrm{~m}^{2}$.

Table 9. Estimates on the cost and return of different grafted tomato (Solanum lycopersicum L) cultivars grown in open field and protected cropping planted in ACIAR-ICM site, Department of horticulture, Visayas State University, Visca, Baybay City, Leyte on July to October 2016

\begin{tabular}{|c|c|c|c|c|}
\hline Treatment & $\begin{array}{c}\text { Total yield } \\
\left(\mathrm{kg} \text { per } 200 \mathrm{~m}^{2}\right)\end{array}$ & $\begin{array}{c}\text { Total variable } \\
\text { cost (PHP) }\end{array}$ & $\begin{array}{c}\text { Gross income } \\
(\mathrm{PHP})\end{array}$ & Net return (PHP) \\
\hline \multicolumn{5}{|l|}{ Open Field } \\
\hline Agatona & 183.20 & $1,056.75$ & $9,160.00$ & $8,103.25$ \\
\hline Discovery & 54.86 & $1,056.75$ & $2,743.00$ & $1,686.25$ \\
\hline Atlas & 178.33 & $1,056.75$ & $8,916.50$ & $7,859.75$ \\
\hline Diamante max & 192.14 & $1,056.75$ & $9,607.00$ & $8,550.25$ \\
\hline Kingkong & 146.69 & $1,056.75$ & $7,334.50$ & $6,277.75$ \\
\hline Season red & 240.88 & $1,056.75$ & $12,044.00$ & $10,987.25$ \\
\hline \multicolumn{5}{|l|}{ Protected } \\
\hline Agatona & 371.35 & $1,453.58$ & $18,567.50$ & $17,113.93$ \\
\hline Discovery & 207.78 & $1,453.58$ & $10,389.00$ & $8,935.43$ \\
\hline Atlas & 339.33 & $1,453.58$ & $16,966.50$ & $15,512.93$ \\
\hline Diamante max & 543.70 & $1,453.58$ & $27,185.00$ & $25,731.43$ \\
\hline Kingkong & 219.46 & $1,453.58$ & $10,973.00$ & $9,519.43$ \\
\hline Season red & 437.96 & $1,453.58$ & $21,898.00$ & $20,444.43$ \\
\hline
\end{tabular}


Growth and yield of non-grafted and grafted tomato

\section{CONCLUSION}

This study has investigated different tomato cultivars planted in bacterial wilt infected field with grafting and no graft under house-type structure and open field to determine the performance, resistance to bacterial wilt and profitability. The results of this investigation shown that protected cropping of tomato increased number of marketable fruits and total yield by approximately 2 times fold than those grown in open field. The grafting of the cultivars to eggplant significantly reduced BWI such that increased survival among plants resulted to higher yield than non-grafted. The cultivar with biggest fruit was from 'Kingkong' while season red had the smallest and other cultivars were in average size of the two. Grafted Diamante max cultivar yielded the highest followed by Season red. Tomato grown in bacterial wilt infected area without grafting was unprofitable. On the other hand, grafting resulted in better yield, gross income and a positive net return. Season red produced the highest income in the open field while Diamante max for protected cultivation.

\section{RECOMMENDATION}

Grafting tomato onto eggplant is strongly recommended for planting in areas known to have bacterial wilt problems. The best cultivars to use when grafting include Season red for open field production, and Diamante max for protected cropping. If grafting is not possible, Agatona can be used which has medium resistance to bacterial wilt. It is also recommended to use a protective structure for tomato production for consistent protection against adverse environmental conditions.

\section{ACKNOWLEDGEMENT}

The researchers would like to thank ACIAR for the research funds, to PCAARRD and to everyone who has contributed to this experiment.

\section{REFERENCES}

Abrantes OF JR. 2013. Performance of Grafted and Pruned Tomato (Lycopersicon esculentum Mill.) under Protective Structure and Open Field (Undergraduate thesis). Visayas State University, Leyte, Philippines

Aganon CP, Mateo LG, Cacho D, Bala A \& Aganon TM. 2004. Enhancing Off-season production through grafted tomato technology. Crop Science Society of the Philippines. Philippine Journal of Crop Science 27(2):3-9

Borines LM, Gonzaga ZC, Capuno OB, Gerona RG, Lusanta DC, Dimabuyu HB, Vega MLP \& Rogers GS. 2016. Disease of Commonly Affecting Vegetables in Eastern Visayas, Philippines, and their Incidence under Protective structure and in the open Field. Acta Horticulturae 1128:117-124. doi:10.17660/Acta Hortic. 1128.16

Buddenhagen I and Kelman A. 1964. Biological and Physiological Aspects of Bacterial wilt caused by Pseudomonas solanacearum. Annual Review of Phytopathology 2:203-230

Dimabuyu HB, Gonzaga ZC, Lusanta DC, Mangmang JS, Capuno OB \& Rogers GS. 2016. Reducing Disease Incidence and Increasing Productivity of Ampalaya (Momordica charantia L.) through Pruning and Protected Cultivation. Acta 
Gonzaga et al

Horticulturae 1128:177-182. doi :10.17660/ActaHortic.2016.1128.26

Food and Agriculture Organization of the United Nations (FAO) Database Statistic. 2000. Retrieved from www.vegetableipmasia.org on 3 April 2016

Gonzaga ZC, Capuno OB, Loreto MB, Gerona RG, Borines LM, Tulin AT, Mangmang JS, Lusanta DC, Dimabuyu HB \& Rogers GS. 2013. Low-cost protected cultivation: Enhancing year-round production of high value vegetables in the Philippines. In Oakeshott J and Hall D (eds) Smallholder HOPES-horticulture, people and soil (pp298). ACIAR

Gorme ALG. 2016. Influence of Different Soil Organic Amendments on the Growth and Yield of Tomato (Solanum Lycopersicum L.) grown under Two Types of Cultivation System (Undergraduate thesis). Visayas State University, Baybay City, Leyte, Philippines

Hayward AC. 1991. Biology and epidemiology of bacterial wilt caused by Pseudomonas solanacearum. Annual Review of Phytopathology 29:65-87

Ioannou N. 2001. Integrating soil solarization with grafting on resistant rootstocks for management of soil-borne pathogens of eggplant. Journal of Horticultural Science and Biotechnology 76:396-401

Kelman A. 1993. The bacterial wilt caused by Pseudomonas solanacearum. A literary review and bibliography. Technical Bulletin of North Carolina Agricultural Experiment Station 99

Khah EM, Kakava E, Mavromatis A, Chachalis D \& Goulas C. 2006. Effect of grafting on growth and yield of tomato (Lycopersicon esculentum Mill.) in greenhouse and open-field. Journal of Applied Horticulture 8:3-7

Lacostales LE. 2015. Influence of Mulching Materials on the Growth and Yield of Sweet Pepper (Capsicum annum L.) grown in Two Types of Cultivation Systems (MS thesis). Visayas State University, Baybay City, Leyte, Philippines

Periago MJ, García-Alonso J \& Jacob K. 2009. Bioactive compounds, folates and antioxidant properties of tomatoes (Lycopersicum esculentum) during vine ripening. International Journal of Food Sciences and Nutrition 60(8):694-708

Sandri MA, Andriolo JL, Witter M \& Dal Ross T. 2003. Effect of shading on tomato plant grow under greenhouse. Horticultura Brasileira 21:642-645

Santos BM, Vallad G \& Torres-Quezada EA. 2013. Protected Culture for Vegetable and Small Fruit Crops: Types of Structures. Horticultural Sciences Department, UF/IFAS Extension. HS1224. Retrieved from edis.ifas. ufl.edu on 2 April 2016

Sharoni $Y$ and Levi Y. 2006. Cancer prevention by dietary tomato lycopene and its molecular mechanisms. In Rao AV (ed) Tomatoes, Lycopene \& Human Health (pp111-125). Caledonian Science Press Ltd, Barcelona, Spain

Sumalinog RR. 2015. Influence of Different Organic and Colored Plastic Mulches on the Growth and Yield of Tomato (Solanum lycopersicum L.) grown in the Open Field and Protective Structure (MS thesis). Visayas State University, Baybay City, Leyte, Philippines

Taylor JH. 1987. Text of lectures delivered at the national workshop on fruit and vegetable seedlings production held at NIHORT 9-13 Technicon Instrument Corporation (1975). Industrial method No. 155-71 W

Tuyan WO. 2015. Growth and Yield of Bitter Gourd (Momordica charantia L.) as Influenced by Organic and Colored Plastic Mulches under Two Types of Cultivation System (MS thesis). Visayas State University, Leyte, Philippines

Willcox JK, Catignani GL \& Lazarus S. 2003. Tomatoes and cardiovascular health. Critical Reviews in Food Science and Nutrition 43(1):1-18 